\title{
Faktor-Faktor yang Mempengaruhi Kepuasan Karyawan Kantoran Serta Dampaknya pada Niat untuk Menggunakan Ulang Layanan Aplikasi Go- Food di Pontianak
}

\author{
Akhmad Hitten* \\ Fakultas Ekonomi dan Bisnis, Universitas Tanjungpura, Indonesia \\ Arief Susanto \\ Fakultas Ekonomi dan Bisnis, Universitas Tanjungpura, Indonesia
}

\begin{abstract}
The objectives of this research are to test the effect of peceived of usefullness, perceived ease of use, perceived of price on the intention to reuse the application Go Food, mediated by consumer satisfaction. The samples of the research were have been selected by using purposive sampling which is taking sample based on characteristics and the objective of the study. The data from this research is analyzed with WarpPLS by applying Structual Equation Model (SEM). The hypothesis is tested by using WarpPLS 6.0 program. The result shows that the perceived usefulness and perceived of price is has significant effect on consumer satisfaction whereas perceived ease of use do not have effect on consumer satisfaction, and consumer satisfaction is significantly effect on intention to reuse the application of Go-Food.
\end{abstract}

JEL : M0

Keywords : perceived usefulness, perceived ease of use, perceived of price, consumer satisfaction

\section{PENDAHULUAN}

Teknologi informasi yang semakin canggih dirancang dalam mempermudah pekerjaan manusia dengan harapan dapat memenuhi kebutuhan informasi seputar dunia bisnis. Salah satu kecanggihan teknologi informasi tersebut adalah adanya internet yang memungkinkan terwujudnya pelayanan terbaik bagi para penggunanya. Berdasarkan survei yang dilakukan Asosiasi Penyelenggara Jaringan Internet Indonesia (APJII) yang menemukan bahwa sepanjang tahun 2016 sebanyak 132,7 juta orang dari sebanyak 256,2 juta orang penduduk Indonesia telah terhubung ke internet. Hal ini berarti sebanyak 51,8\% penduduk Indonesia telah menjadi netter.

Perkembangan internet yang semakin pesat juga mempengaruhi dunia bisnis. Saat ini semakin banyak bermunculan layanan aplikasi berbasis online. Layanan aplikasi berbasis online ini tentu akan memberikan kemudahan bagi para pengguna karena mereka hanya

\footnotetext{
*E-mail : akhmadhiten@gmail.com

Received : 27-07-2018, Accepted : 06-11-2018, Published : 29-08-2019

P-ISSN : 2087 - 9954, E-ISSN : 2550 - 0066. DOI : http://dx.doi.org/10.26418/jebik.v8i2.26851
} 
memerlukan smartphone untuk menggunakannya kapanpun dan dimanapun. Inovasi ini mendorong munculnya berbagai aplikasi yang bersaing dalam memberikan layanan online terbaik. Salah satu aplikasi yang muncul adalah layanan aplikasi Gofood dari Go-Jek. Gofood sendiri adalah layanan untuk memesan makanan secara online dan akan diantarkan ke tempat pembeli langsung oleh driver Gojek. Jelas bahwa visi utama layanan tersebut adalah memberikan kemudahan kepada para pengguna. Kemudahan tersebut antara lain efektifitas dan efisiensi waktu.

Sebuah aplikasi yang merupakan bagian dari sistem informasi dapat diukur tingkat penerimaannya dengan beberapa model. Salah satu model yang dapat digunakan yaitu Technology Acceptance Model (TAM) yang dikenalkan oleh Fred D. Davis (1989). Model penerimaan teknologi (Technology Acceptance Model/TAM) merupakan suatu model penerimaan sistem teknologi informasi yang akan digunakan oleh pemakai (Hartono, 2008). Model penerimaan teknologi mempostulasikan dua konstruk utama sebagai keyakinan perilaku penerimaan teknologi informasi yaitu persepsi kegunaan (perceived usefulness) dan persepsi kemudahan penggunaan (perceived ease of use). Persepsi kegunaan (perceived usefulness) merupakan salah satu komponen yang mempengaruhi penerimaan teknologi bagi seseorang. Sedangkan persepsi kemudahan penggunaan (perceived ease of use) didasarkan pada sejauh mana calon pengguna mengharapkan sistem baru yang akan digunakan terbebas dari kesulitan (Aditya \& Wardhana, 2016). Menurut penelitian yang dilakukan oleh Wen, Prybutok, \& Xu (2011), persepsi kegunaan dan persepsi kemudahan penggunaan mempengaruhi kepuasan konsumen.

Dalam setiap bisnis, tentu harga akan menjadi salah satu faktor penting yang menjadi perhatian baik itu dari pihak penjual (produsen) maupun pihak pembeli (konsumen). Hal ini juga berlaku bagi aktivitas bisnis berbasis online. Salah satu hal yang menarik dari Go-Jek adalah pembeli dapat membayar harga yang tertera pada smartphone mereka dengan menggunakan uang virtual yang dikenal dengan Go-Pay yang juga berlaku bagi layanan Gofood sehingga pembeli tidak perlu repot melakukan transfer ataupun membawa uang cash ketika melakukan pembayaran atas makanan yang telah dipesan. Menurut penelitian Kurniawan, Santoso, \& Dwiyanto (2007), faktor-faktor yang mempengaruhi niat beli ulang konsumen antara lain kualitas produk, intensitas promosi, dan harga yang dirasakan. Penelitian yang dilakukan oleh Palma \& Andjarwati (2016) menunjukkan bahwa kepuasan konsumen juga memediasi hubungan antara persepsi kemudahan penggunaan dengan minat menggunakan ulang. Hubungan antara persepsi harga terhadap minat beli ulang juga dimediasi oleh kepuasan konsumen (Jiang \& Rosenbloom, 2004; Resti \& Soesanto, 2016). Dari beberapa penelitian tersebut membuat peneliti menjadikan kepuasan konsumen sebagai variabel yang mediasi dalam penelitian ini.

Berdasarkan latar belakang yang telah diuraikan diatas, maka artikel ini akan membuat penelitian yang berjudul "Faktor-Faktor yang Mempengaruhi Kepuasan Karyawan Kantoran Serta Dampaknya pada Niat untuk Menggunakan Ulang Layanan Aplikasi Go-Food di Pontianak."

\section{KAJIAN LITERATUR}

a. Pengaruh antara Persepsi Kegunaan dengan Kepuasan Konsumen 
Yang dan Peterson (2004) dalam Vinerean (2013) mengemukakan bahwa: Jika persepsi kemudahan penggunaan dan persepsi kegunaan (persepsi kegunaan) konsumen dalam berbelanja menggunakan internet tidak meringankan beban konsumen yang disebabkan karena pengalaman pribadi, kesulitan teknis, dan usaha untuk mempelajari, maka konsumen akan lebih memilih untuk kembali melakukan pembelian dengan cara tradisional. Persepsi kegunaan berpengaruh positif terhadap kepuasan konsumen. Semakin tinggi manfaat aplikasi bagi pengguna maka konsumen akan semakin puas. Pernyataan ini didukung dengan penelitian yang dilakukan oleh Amin, Rezaei, \& Abolghasemi, 2014; Putrina, 2018; Trisnawati, Suroso, \& Kumorohadi, 2012; Vinerean, 2013; Wen et al., 2011.

\section{b. Pengaruh antara Persepsi Kemudahan Penggunaan dengan Kepuasan Konsumen}

Jika konsumen merasa puas dengan suatu aplikasi, maka dia akan menggunakannya di kemudian hari. Semakin mudah seorang konsumen memperoleh hal yang diinginkannya maka semakin tinggi tingkat kepuasannya (Palma \& Andjarwati, 2016). Berdasarkan penelitian yang dilakukan oleh Amin et al. (2014), salah satu faktor yang mempengaruhi kepuasan konsumen adalah persepsi kemudahan penggunaan. Hal ini diperkuat dengan temuan Muflihhadi \& Rubiyanti, 2016; Widiana, Supit, \& Hartini, 2012.

\section{c. Pengaruh antara Persepsi Harga dengan Kepuasan Konsumen}

Dalam kondisi kinerja produk yang belum diketahui, persepsi harga memegang peranan dalam menggambarkan kesesuaian antara apa yang ada pada website dengan apa yang akan konsumen terima (Jiang \& Rosenbloom, 2004). Semakin sesuai harga yang diperoleh pelanggan untuk suatu produk, maka semakin meningkat kepuasan para pelanggan (Palma \& Andjarwati, 2016). Berdasarkan penelitian yang dilakukan oleh Jiang \& Rosenbloom, 2004; Palma \& Andjarwati, 2016, ditemukan bahwa persepi harga mempengaruhi kepuasan konsumen secara positif.

\section{d. Pengaruh antara Kepuasan Konsumen dengan Niat Menggunakan Ulang}

Niat beli ulang adalah suatu perilaku pelanggan dimana pelanggan merespon positif terhadap kualitas pelayanan suatu perusahaan dan berniat melakukan kunjungan kembali atau mengkonsumsi kembali produk perusahaan tersebut (Cronin, dkk. 1992 dalam Prabowo, 2016). Dholakia (2010) dalam Palma \& Andjarwati (2016) mengatakan bahwa kepuasan konsumen sangat berpengaruh besar terhadap niat pembelian ulang. Kepuasan konsumen berpengaruh positif terhadap minat menggunakan ulang, hal ini dibuktikan dengan penelitian yang dilakukan oleh Lin \& Lekhawipat, 2014; Palma \& Andjarwati, 2016.

Berdasarkan penjelasan di atas, maka hipotesis dan kerangka penelitian dalam penelitian ini adalah sebagai berikut:

$\mathrm{H}_{1}$ : Persepsi kegunaan berpengaruh positif terhadap kepuasan konsumen.

$\mathrm{H}_{2}$ : Persepsi kemudahan penggunaan berpengaruh positif terhadap kepuasan konsumen.

$\mathrm{H}_{3}$ : Persepsi harga berpengaruh positif terhadap kepuasan konsumen.

H4: Kepuasan konsumen berpengaruh positif terhadap minat menggunakan ulang. 


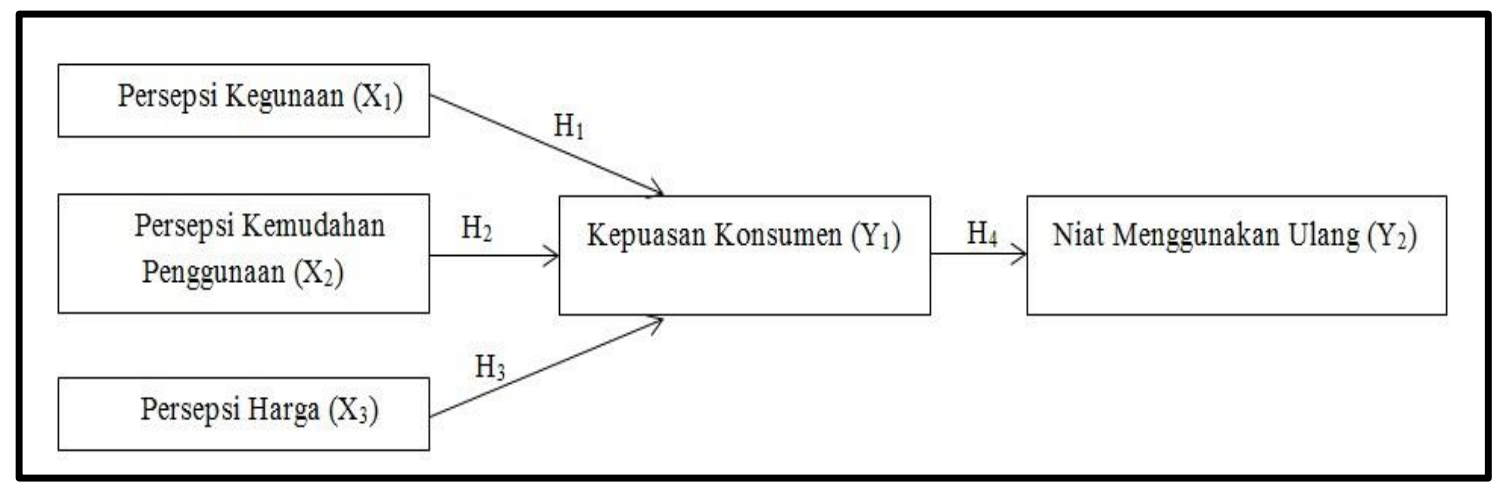

Gambar 1. Kerangka Penelitian

\section{METODA PENELITIAN}

Penelitian ini adalah penelitian kuantitatif asosiatif dengan unit analisis yang diteliti adalah karyawan kantoran di Pontianak Kalimantan Barat yang menggunakan layanan aplikasi Go-Food. Penelitian kuantitatif asosiatif adalah penelitian yang bertujuan untuk mengetahui hubungan dua variabel atau lebih (Sugiyono, 2012). Penelitian ini termasuk dalam penelitian eksplanasi (explanatory research) berdasarkan jenis penelitian. Penelitian eksplanasi digunakan untuk menganalisis hubungan-hubungan antara satu variabel dengan variabel lainnya atau bagaimana suatu variabel mempengaruhi variabel lainnya melalui pengujian hipotesis (Sugiyono, 2012). Penelitian ini bertujuan untuk mengetahui faktor persepsi kegunaan ( $\left.X_{1}\right)$, persepsi kemudahan penggunaan $\left(\mathrm{X}_{2}\right)$, dan persepsi harga $\left(\mathrm{X}_{3}\right)$, berpengaruh terhadap kepuasan konsumen ( $\left.\mathrm{Y}_{1}\right)$ serta dampaknya terhadap niat menggunakan ulang $\left(\mathrm{Y}_{2}\right)$ layanan aplikasi GoFood di Kota Pontianak, Kalimantan Barat.

Jumlah karyawan kantoran yang pernah menggunakan layanan aplikasi Go-Food masih belum diketahui, sehingga dapat disimpulkan bahwa populasi dalam penelitian ini merupakan infinite population dan metode sampling yang digunakan dalam penelitian ini adalah nonprobability sam-pling, di mana besarnya peluang atau probabilitas elemen populasi untuk terpilih sebagai subyek sampel tidak diketahui (Sekaran, 2006:127). Teknik pengambilan sampling pada penelitian ini menggunakan teknik Purposive Sampling, tipe desain pengambilan sampel berdasarkan pertimbangan tertentu (judgmental sampling), yaitu pengambilan sampel terbatas pada karyawan kantor Go Food yang dapat memberikan informasi yang diinginkan berdasarkan pertimbangan tertentu (Sekaran, 2006). Adapun karakteristik yang harus dimiliki oleh responden sebagai pertimbangan untuk pengambilan sampel dalam penelitian ini yaitu karyawan kantoran yang menggunakan layanan aplikasi Go-Food.

Jenis data dalam penelitian ini adalah data primer yaitu data yang diperoleh secara langsung dari responden yang mengisi kuesioner. Metode analisis yang digunakan dalam penelitian ini adalah metode analisis kuantitatif. Analisis data kuantitatif ini diawali dengan mengumpulkan data-data yang mewakili sampel dalam penelitian ini, kemudian data-data tersebut diolah dengan menggunakan WarpPLS 6.0 sehingga akan dihasilkan olahan data dalam bentuk tabel, grafik, serta kesimpulan yang berfungsi untuk mengambil keputusan atas hasil 
analisis. Teknik analisis data yang digunakan dalam penelitian ini adalah Structural Equation Model (SEM).

\section{HASIL PENELITIAN DAN PEMBAHASAN}

Penelitian ini menggunakan uji model pengukuran (outer model) dan model struktural (inner model). Model pengukuran (outer model) dibuat untuk menguji hubungan indikator terhadap variabel laten, atau dengan kata lain mengukur seberapa jauh indikator itu dapat menjelaskan variabel latennya. Sedangkan inner model (inner relation, structural model dan substantive theory) menggambarkan hubungan antara variabel laten berdasarkan pada teori substantif.

Evaluasi outer model dilakukan melalui tiga tahap pengujian yaitu convergent validity, discriminant validity, dan composite reliability. Berikut adalah hasil pengujian outer model. Menurut Hair dkk (2013) dalam Sholihin \& Ratmono (2013), terdapat dua kriteria untuk menilai apakah outer model memenuhi syarat validitas konvergen untuk konstruk reflektif yaitu (1) loading harus di atas 0,70 dan (2) nilai p siginifikan $(<0,05)$. Pada penelitian ini, hasil pengujian menunjukkan dari 17 indikator yang diuji, semua indikator dinyatakan valid karena nilai loadingnya berada di atas 0,70 dan nilai siginifikan $\mathrm{p}$ dibawah 0,05 .

Menurut Sholihin \& Ratmono (2013) kriteria yang digunakan untuk mengukur validitas diskriminan dalam penelitian adalah akar kuadrat (square roots) average variance extracted (AVE) yaitu kolom diagonal dan diberi tanda kurung; harus lebih tinggi dari korelasi antar variabel laten pada kolom yang sama (diatas atau dibawahnya). Hasil analisis menunjukkan bahwa validitas diskriminan telah terpenuhi dan memiliki nilai yang baik. Reliabilitas variabel dapat dilihat dari output laten variable coefficients yang menyajikan dua ukuran yaitu composite reliability dan cronbach's alpha. Kriteria yang digunakan sebagai syarat reliabilitas suatu konstruk penelitian adalah nilai composite reliability harus $>0,70$ dan nilai cronbach's alpha harus lebih dari 0,60. Average variance extracted (AVE) juga digunakan untuk evaluasi validitas konvergen dimana kriterianya harus di atas 0,50 untuk menunjukkan kriteria reliabilitas telah terpenuhi (Fornell dan Lacker, 1981 dalam Sholihin \& Ratmono, 2013). Hasil analisis menunjukkan bahwa kelima konstruk penelitian, satu konstruk dinyatakan tidak reliable karena tidak memenuhi syarat yaitu nilai composite reliability berada di bawah 0,70 dan nilai cronbach's alpha berada di bawah 0,60 . Nilai composite reliability yang dimiliki oleh persepsi kegunaan sebesar 0,840, persepsi kemudahan penggunaan sebesar 0,911, persepsi harga sebesar 0,878, kepuasan konsumen sebesar 0,975, dan niat menggunakan ulang sebesar 0,888 .

Evaluasi terhadap model structural dapat ditunjukkan melalui nilai $R$-squared dan $Q$-squared predictive relevance. Nilai $\mathrm{R}$-squared $\left(\mathrm{R}^{2}\right)$ digunakan untuk menilai seberapa besar pengaruh variabel laten independen tertentu terhadap variabel laten dependen. Berdasarkan hasil pengolahan data, R-squared untuk konstruk Kepuasan Konsumen sebesar 0,518 yang menunjukkan bahwa variansi minat menggunakan dapat dijelaskan 51,8\% oleh variansi persepsi kegunaan, persepsi kemudahan penggunaan, dan persepsi harga. Sedangkan R-squared untuk konstruk niat menggunakan ulang sebesar 0,497 yang menunjukkan bahwa variansi penggunaan aktual dapat dijelaskan $49,7 \%$ oleh kepuasan konsumen. Model penelitian memiliki relevansi prediksi yang baik jika nilai koefisien Q-squared lebih dari 0 (nol) (Sholihin \& Ratmono, 2013). Nilai Q-squared dapat dilihat pada ouput latent variable coefficients kolom 
bagian Q-squared. Hasil pengujian Q-squared untuk variabel kepuasan konsumen sebesar 0,521 dan untuk variabel niat menggunakan ulang sebesar 0,467. Dengan demikian, hasil estimasi model penelitian ini telah menunjukkan validitas prediktif yang baik karena bernilai di atas nol.

Uji hipotesis dilakukan dengan melihat koefisien jalur untuk mengetahui besarnya pengaruh antar variabel laten dengan cara bootstrapping. Kriteria untuk menentukan diterima atau tidaknya hipotesis adalah $\mathrm{p}$ value harus lebih kecil dari 0,05 untuk toleransi kesalahan (alpha) sebesar 5\%. Berikut ini adalah gambar model struktural penelitian yang dihasilkan dari Warp PLS 6.0.

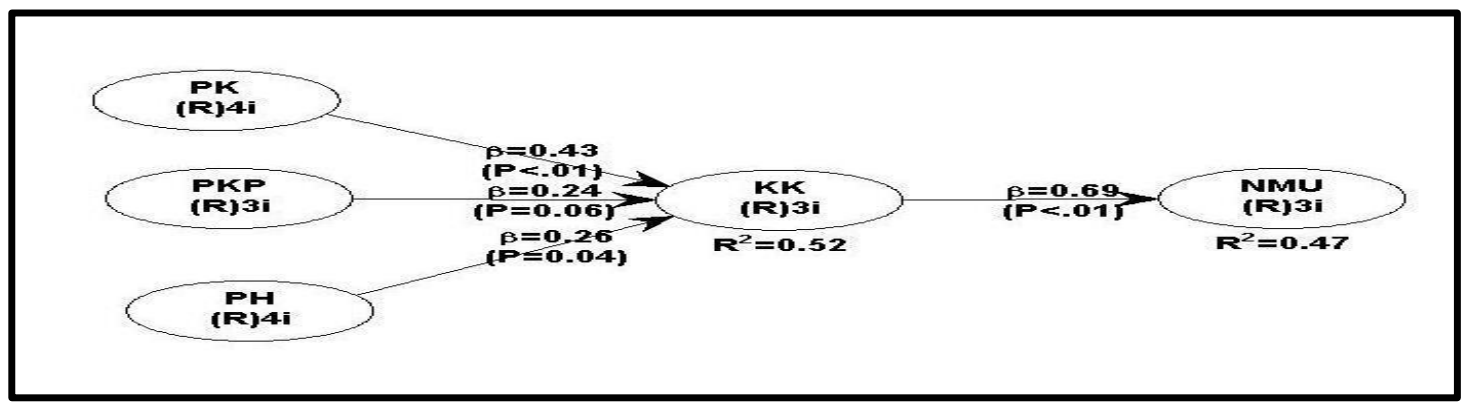

Gambar 2. Model Struktural Penelitian

\subsection{Hipotesis 1}

Persepsi Kegunaan berpengaruh positif dan signifikan terhadap kepuasan konsumen dalam menggunakan layanan aplikasi Go-Food. Berdasarkan Gambar 2 nilai koefisien jalur sebesar 0,43 dan $\mathrm{p}$ value sebesar < 0,01 dengan toleransi kesalahan (alpha) sebesar 5\%. Dengan demikian $\mathrm{H}_{1}$ diterima. Positif berarti ketika konsumen yang dalam penelitian ini merupakan karyawan kantoran merasa aplikasi Go-Food berguna dalam menyediakan makanan bagi mereka pada saat jam makan siang, maka mereka merasa bahwa aplikasi Go-Food berguna dan mereka akan menggunakannya. Namun sebaliknya, ketika konsumen tidak merasa bahwa dengan menggunakan aplikasi Go-Food dapat memperlancar proses penyediaan makanan bagi mereka pada saat jam makan siang, maka mereka merasa bahwa aplikasi Go-Food tidak berguna dan mereka akan enggan untuk menggunakannya.

Persepsi kegunaan merupakan ukuran yang tepat sebelum memutuskan apakah mereka mau menggunakan aplikasi Go-Food atau tetap memaksakan diri untuk membeli makanan sendiri disaat waktu jam makan siang tersisa sedikit lagi. Bagi sebagian besar karyawan kantoran, layanan aplikasi Go-Food telah membantu mereka dalam mengelola waktu istirahat makan siang agar lebih efektif dan efisien. Mereka juga tetap dapat menyelesaikan pekerjaan dengan baik, namun tidak kelewatan jam makan. Dengan demikian, layanan aplikasi Go-Food dapat berguna dan memberikan manfaat bagi karyawan kantoran sehingga menghasilkan kepuasan karena sesuai dengan ekspektasi mereka. Dalam hal ini, ekspektasi tersebut adalah manfaat yang diberikan berupa tersedianya makanan tepat waktu. Penelitian ini didukung penelitian Wen et al. (2011), Amin et al (2014), Widiana et al. (2012), Muflihhadi \& Rubiyanti (2016), serta Mandasari \& Giantari (2017) yang menyatakan bahwa persepsi kegunaan berpengaruh positif terhadap kepuasan konsumen. 


\subsection{Hipotesis 2}

Persepsi kemudahan penggunaan berpengaruh positif dan signifikan terhadap kepuasan konsumen dalam menggunakan layanan aplikasi Go-Food. Berdasarkan Gambar 2 nilai koefisien jalur sebesar 0,24 dan p value sebesar $=0,06$ dengan toleransi kesalahan (alpha) sebesar $5 \%$. Dengan demikian $\mathrm{H}_{2}$ ditolak karena p value $>0,05$. Seperti yang telah dijelaskan sebelumnya bahwa karyawan kantoran merasa puas dengan pelayanan aplikasi Go-Food dikarenakan terbukti bahwa aplikasi Go-Food memberikan manfaat bagi mereka dalam hal penyediaan makanan saat jam makan siang kantor. Namun, bagi sebagian karyawan merasa bahwa cukup sulit ketika harus mengaktifkan smartphone untuk mencari driver Go-Food, kemudian hambatan lain seperti lalu lintas yang padat atau cuaca buruk juga akan memperlambat proses pengantaran makanan oleh driver. Hal ini menjadi alasan bahwa dengan menggunakan aplikasi Go-Food memang memberikan manfaat akan tetapi belum sepenuhnya membebaskan karyawan kantoran dari usaha, sehingga ada ketidakpuasan tersendiri dari mereka. Penelitian ini tidak konsisten dengan penelitian yang dilakukan oleh Amin et al.(2014), Mandasari \& Giantari (2017), Muflihhadi \& Rubiyanti (2016) serta Widiana et al. (2012), yang menyatakan bahwa persepsi kemudahan penggunaan berpengaruh positif terhadap kepuasan konsumen.

\subsection{Hipotesis 3}

Persepsi harga berpengaruh positif dan signifikan terhadap kepuasan konsumen dalam Menggunakan layanan aplikasi Go-Food. Berdasarkan Gambar 2 nilai koefisien jalur sebesar 0,26 dan p value sebesar 0,04 dengan toleransi kesalahan (alpha) sebesar 5\%. Dengan demikian $\mathrm{H}_{3}$ diterima. Semakin sesuai harga yang diperoleh pelanggan untuk suatu produk, maka semakin meningkat kepuasan para pelanggan (Palma \& Andjarwati, 2016). Sebagian besar responden memberikan tanggapan adanya penilaian setuju terhadap persepsi harga pada aplikasi Go-Food. Konsumen merasa bahwa harga dari layanan Go-Food terjangkau dan sesuai dengan kualitas layanan yang diberikan. Harga yang ditawarkan oleh Go-Food dirasakan tidak terlalu mahal dibandingkan dengan perusahaan sejenis. Hal ini didukung pula dengan pemberian potongan harga bagi konsumen yang membayar menggunakan Go-Pay. Hasil penelitian ini menunjukkan bahwa $\mathrm{H}_{3}$ diterima yaitu variabel persepsi harga menjadi salah satu faktor yang berpengaruh terhadap kepuasan konsumen aplikasi Go-Food. Hal ini didukung oleh penelitian yang dilakukan oleh Resti \& Soesanto (2016).

\subsection{Hipotesis 4}

Kepuasan Konsumen berpengaruh positif dan signifikan terhadap niat menggunakan ulang layanan aplikasi Go-Food. Berdasarkan Gambar 2 nilai koefisien jalur sebesar 0,69 dan p value sebesar < 0,01 dengan toleransi kesalahan (alpha) sebesar 5\%, dengan demikian $\mathrm{H} 4$ diterima. Konsumen merasa menggunakan aplikasi Go-Food dapat memberikan kepuasan bagi mereka. Hal ini karena manfaat yang diberikan oleh Go-Food melebihi ekspektasi konsumen mengenai Go-Food. Konsumen juga merasa pelayanan dari Go-Food memuaskan, karena Go-Food memiliki standar layanan yang harus diberikan driver mereka kepada konsumen, seperti selalu menghubungi konsumen baik itu melalui telepon, sms atau chat untuk menyebutkan kembali makanan yang dipesan dan memastikan apakah ada 
tambahan lagi atau tidak, menanyakan dan memastikan alamat makanan akan diantar, memberikan bill dari restoran tempat konsumen memesan makanan dan mengucapkan terima kasih ketika orderan makanan sudah selesai diantar. Layanan-layanan yang tersedia juga sesuai dengan harapan konsumen. Layanan yang ditawarkan oleh aplikasi Go-Food mampu menjawab kebutuhan serta keinginan konsumen yang merupakan karyawan kantoran yang membutuhkan hal-hal yang praktis guna menunjang kesibukan dan keterbatasan manusia modern saat ini. Hasil penelitian ini didukung oleh penelitian yang dilakukan oleh Saragih \& Ramdhany (2012), Wen et al. (2011) dan Widiana et al. (2012).

\section{SIMPULAN}

Berdasarkan hasil analisis dan pembahasan pada bab sebelumnya, maka dapat ditarik kesimpulan sebagai berikut: variabel persepsi kegunaan berpengaruh positif dan signifikan terhadap kepuasan konsumen pada aplikasi Go-Food. Variabel persepsi kemudahan penggunaan tidak berpengaruh signifikan terhadap kepuasan konsumen pada aplikasi Go-Food. Variabel Persepsi Harga berpengaruh positif dan signifikan terhadap kepuasan konsumen pada aplikasi Go-Food. Variabel Kepuasan Konsumen berpengaruh positif dan signifikan terhadap niat menggunakan ulang aplikasi Go-Food dengan nilai signifikansi $\mathrm{p}<0,05$ yaitu sebesar $<0,01$.

\section{DAFTAR PUSTAKA}

Aditya, R., \& Wardhana, A. (2016). Pengaruh Perceived Usefulness dan Perceived Ease of Use terhadap Behavioral Intention dengan Pendekatan Technology Acceptance Model (TAM) pada Pengguna Instant Messaging LINE di Indonesia. Jurnal Siasat Bisnis, 20(1), 24-32. https://doi.org/10.20885/jsb.vol20.iss1.art3.

Amin, M., Rezaei, S., \& Abolghasemi, M. (2014). User Satisfaction with Mobile Websites: the Impact of Perceived Usefulness (PU), Perceived Ease of Use (PEOU) and Trust. Nankai Business Review International, 5(3), 258-274. https://doi.org/https://doi.org/10.1108/NBRI-01-2014-0005

Fred D. Davis. (1989). Perceived Usefulness, Perceived Ease of Use, and User Acceptance of Information Technology. MIS Quarterly, 13(3), 319-340. https://doi.org/10.1016/j.cell.2017.08.036.

Hartono, J. (2008). Behavioral Information System. Yogyakarta: ANDI.

Jiang, P., \& Rosenbloom, B. (2004). Customer Intention to Return Online: Price Perception, Attribute-Level Performance, and Satisfaction Unfolding Over Time. European Journal of Marketing, 39(1-2), 150-174. https://doi.org/10.1108/03090560510572061.

Kurniawan, I., Santoso, S. B., \& Dwiyanto, B. M. (2007). Analisis Faktor- Faktor Yang Mempengaruhi Minat Beli Ulang Produk Serta Dampaknya terhadap Loyalitas Pelanggan (Studi Kasus Pada Produk Sakatonik Liver di Kota Semarang). Jurnal Studi Manajemen \& Organisasi, 24(2), 27-42. https://doi.org/10.33633/jpeb.v2i1.2231.

Lin, C., \& Lekhawipat, W. (2014). Factors Affecting Online Repurchase Intention. Industrial Management \& Data Systems, 114(4), 597-611. https://doi.org/https://doi.org/10.1108/IMDS-10-2013-0432. 
Mandasari, I. A. C. S., \& Giantari, I. G. A. K. (2017). Pengaruh Perceived Usefulness, Perceived Ease of Use, dan Kualitas Layanan terhadap Kepuasan untuk Membangun Loyalitas. EJurnal Ekonomi dan Bisnis Universitas Udayana, 6(10), 3637-3664.

Muflihhadi, I., \& Rubiyanti, R. N. (2016). Pengaruh Perceived Usefulness , Perceived Ease of Use, dan Trust Terhadap Kepuasan Konsumen (Studi Pada Gojek Bandung). E-Proceeding of Management, 3(2), 2026-2033.

Palma, M. A., \& Andjarwati, A. L. (2016). Pengaruh Kualitas Produk, Kemudahan, dan Harga terhadap Niat Beli Ulang dengan Kepuasan sebagai Variabel Intervening (Studi pada Pelanggan Produk Fashion melalui Toko Online di Surabaya). Journal of Research in Economics and Management, 16(1), 84-104. Retrieved from https://www.techdirt.com/articles/20160222/09101033670/google-fiber-expanding-fasterfurther-making-comcast-very-nervous.shtml

Prabowo, P. B. (2016). Analisis Persepsi Konsumen tentang Isyarat Ekstrinsik dan Intrinsik Obat Penurun Bodrex dan Dampaknya terhadap Minat Beli Ulang di Kota Pontianak. Jurnal Manajemen Update, 5(2).

Putrina, M. (2018). Pengaruh Persepsi Kebermanfaatan, Persepsi Kemudahan Penggunaan, dan Persepsi Harga terhadap Kepuasan Konsumen yang Berdampak pada Minat Menggunakan Ulang Aplikasi Go-jek di Kota Pontianak. Jurnal Manajemen Update, 7(1).

Resti, D., \& Soesanto, H. (2016). Pengaruh Persepsi Harga, Kualitas Pelayanan, Melalui Kepuasan Pelanggan terhadap Minat Beli Ulang pada Rumah Kecantikan Sifra di Pati. Diponegoro Journal of Management, 5(1), 1-12.

Saragih, H., \& Ramdhany, R. (2012). Pengaruh Intensi Pelanggan dalam Berbelanja Online Kembali Melalui Media Teknologi Informasi Forum Jual Beli (Fjb) Kaskus. Jurnal Sistem Informasi, 8(2), 10112. https://doi.org/10.21609/jsi.v8i2.331

Sekaran, U. (2006). Metodologi Penelitian untuk Bisnis (4th ed.). Jakarta: Salemba Empat.

Sholihin, M., \& Ratmono, D. (2013). Analisis SEM-PLS Dengan WarpPLS 3.0 Untuk Hubungan Nonlinier Dalam Penelitian Sosial Dan Bisnis. ANDI. Retrieved from http://library.ukdw.ac.id/main/opac/index.php?p=show_detail\&id=44368

Sugiyono. (2012). Metode Penelitian Kuantitatif Kualitatif dan R\&D. Bandung: Alfabeta.

Trisnawati, E., Suroso, A., \& Kumorohadi, U. (2012). Analisis Faktor-Faktor Kunci dari Niat Pembelian Kembali secara Online (Studi Kasus pada Konsumen Fesh Shop). Jurnal Bisnis dan Ekonomi (JBE), 19(2), 126-141. https://doi.org/1412-3126

Vinerean, S. (2013). The Impact of Customer Perceptions and Satisfaction on E-Loyalty. Expert Journal of Marketing, 1(1), 4-16.

Wen, C., Prybutok, V. R., \& Xu, C. (2011). An Integrated Model for Customer Online Repurchase Intention. Journal of Computer Information Systems, 52(1), 14-23.

Widiana, M. E., Supit, H., \& Hartini, S. (2012). Penggunaan Teknologi Internet dalam Sistem Penjualan Online untuk Meningkatkan Kepuasan dan Pembelian Berulang Produk Batik pada Usaha Kecil dan Menengah di Jawa Timur. Jurnal Manajemen dan Kewirausahaan, 14(1), 71-81. https://doi.org/10.9744/jmk.14.1.72-82. 